\title{
Assessment of the withdrawal period for ractopamine hydrochloride in the goat and sheep
}

\author{
M. Lazuardi ${ }^{1}$, B. Hermanto ${ }^{2}$ and T.I. Restiadi ${ }^{3}$ \\ ${ }^{1}$ Laboratory of Veterinary Pharmacy Science, ${ }^{3}$ Departement of Reproduction, Faculty of Veterinary Medicine, ${ }^{2}$ Department of \\ Pharmacology, Medical Faculty, University of Airlangga , Surabaya, Indonesia \\ Email: ${ }^{1}$ lazuardi@fkh.unair.ac.id, ${ }^{2}$ bambang-h@fk.unair.ac.id, ${ }^{3}$ tjukir@yahoo.com
}

(Received September 18, 2019; Accepted October 13, 2019; Available online July 25, 2020)

\begin{abstract}
Ractopamine hydrochloride often used as a bronchodilator, but its $\beta$-adrenergic agonist effects on un-striated muscle and its withdrawal time have not been assessed for Etawah goats and sheep. The aim of this study was to determine the safe time to slaughter goats and sheep post-treatment with ractopamine. Five clinically healthy adult goats and sheep ( $20 \mathrm{~kg}$ body weight) were treated with a single dose of ractopamine ( $1 \mathrm{mg}$, intravenously). Whole blood was sampled from the jugular vein at 120 min, 180 min and 300 min post-treatment. Ractopamine as a veterinary drug was analysed using HPLC at wavelength $225 \mathrm{~nm}$. The concentrations at $120 \mathrm{~min}, 180 \mathrm{~min}$ and $300 \mathrm{~min}$ were $817.156 \pm 13.460 \mu \mathrm{g} \cdot \mathrm{mL}^{-1}$, $554.468 \pm 50.157 \mu \mathrm{g} . \mathrm{mL}^{-1}$, and 294.588 $\pm 52.845 \mu \mathrm{g} \cdot \mathrm{mL}^{-1}$ in goats and $706.266 \pm 89.856 \mu \mathrm{g} \cdot \mathrm{mL}^{-1}, 579.194 \pm 45.664 \mu \mathrm{g} \cdot \mathrm{mL}^{-1}$, and $209.36 \pm 54.797 \mu \mathrm{g} \cdot \mathrm{mL}^{-1}$ in sheep, respectively. The withdrawal times in goats and sheep were $1141.710 \pm 255.85 \mathrm{~h}$ and $989.741 \pm 167.633 \mathrm{~h}$, respectively, no drug residues detected. The safe time to slaughter goats after administration of $1 \mathrm{mg}$ of ractopamine was approximately 3 months and 5 days post-treatment at a safety factor of 2 , which was later than the sheep at 2 months and 22 days by a safety factor of two.
\end{abstract}

Keywords: $\beta$-agonist, Clenbuterol, Vetranal, Residues

DOI: 10.33899/ijvs.2019.126114.1237, (C2020, College of Veterinary Medicine, University of Mosul.

This is an open access article under the CC BY 4.0 license (http://creativecommons.org/licenses/by/4.0/).

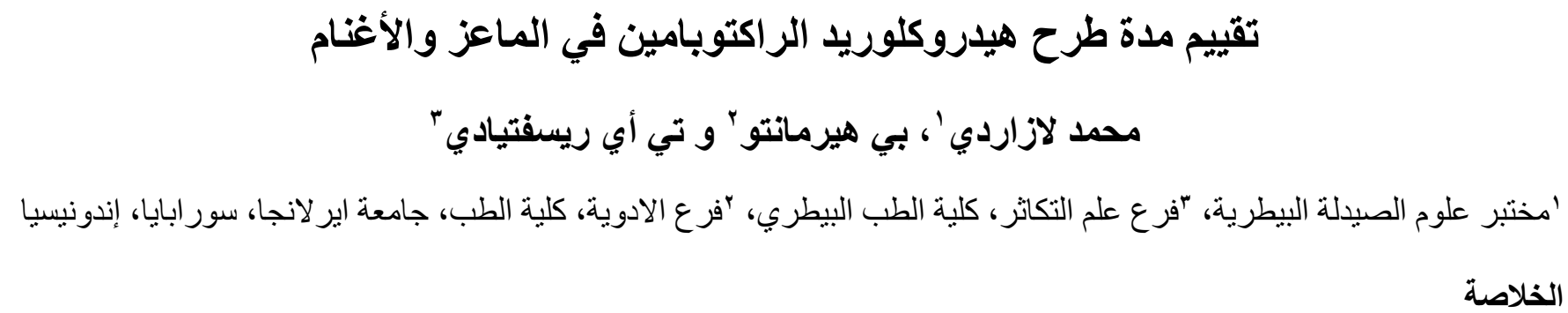

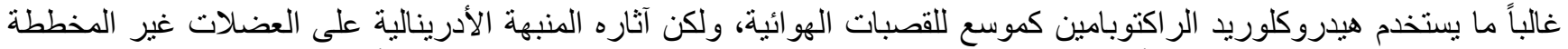

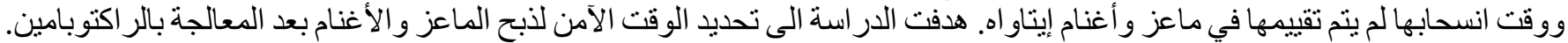

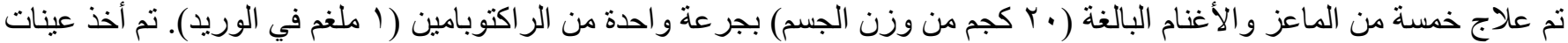

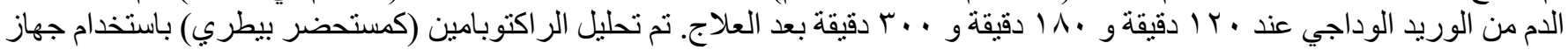
HPLC

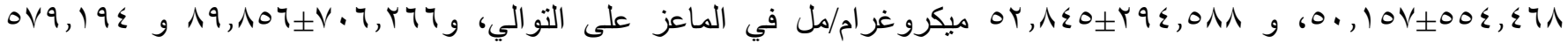

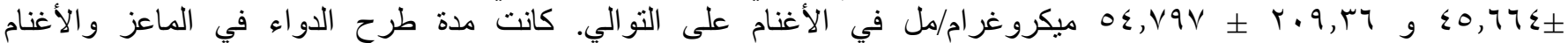

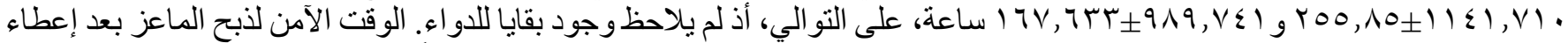

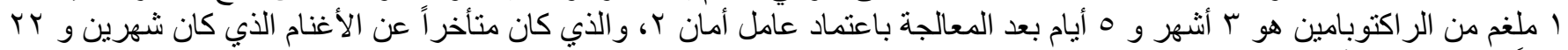

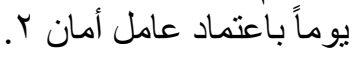




\section{Introduction}

$\beta$-Agonists exhibit short-acting effects and long-acting effects and are frequently used to promote growth in livestock, but problems arise when the residues of such veterinary drugs have the potential to influence human health after being consumed in animal products (1-5). Evaluation of $\beta$-agonist as a veterinary drug is a new concept to implement the principle using medicines for veterinarian by motto: logic and responsibility. Logic in science has the following characteristics: a methodology, based on evidence and theory update. Responsibility means that a professional veterinarian has a moral responsibility to monitor the effects of administration of a drug that they have recommended (6).

In early 2018, a new concept for calculation of withdrawal time was developed on the basis of pharmacokinetic and bio-analysis data. This improved approach permits the calculation of withdrawal periods for veterinary drugs in any local animal, so it logical to use it to re-assess the current withdrawal period for ractopamine (7).

It was therefore decided to use this updated approach to re-assess the withdrawal period of ractopamine after treatment in goats and sheep, both of which are distributed across Asia, Europe, Australia and Africa, where they are used to produce human food, drugs and cosmetics. They are also closely related to livestock in several countries that are free from adverse drug responses (8). Specifically, we tested whether the withdrawal period of ractopamine, after a single dose was administered intravenously, differs between Indonesian (Etawah) goats and sheep (9). A second goal was to determine the length of time required for $\beta$-agonist residues to decrease to safe levels in animals that are to be slaughtered post-treatment.

\section{Materials and methods}

\section{Experiment animals and animal ethic clearance}

This research was conducted at Airlangga University in collaboration with the Indonesia Veterinary Pharmacy and Pharmacology Association under control by the Indonesia Medical Veterinary Association (IMVA) from August 2016 to August 2018, with rainy conditions and subtropical temperatures of approximately $22-25^{\circ} \mathrm{C}$, and was conducted in compliance with the animal ethics clearance from University of Airlangga. Etawah goats and Javanese thintailed sheep, both local Indonesian breeds, were obtained from local farmers in Surabaya, Indonesia. The study was conducted in five of goats and five of sheep. The criteria of experimental animals were from the second generations of the native species of goats and sheep and were healthy adult males aged 1 year (live weight $18-22 \pm 1.41 \mathrm{~kg}$ ) raised under controlled veterinarian practices. Before treatment, all animals were adapted in animal housing for approximately 2 weeks.

\section{Research design and experimental protocol}

The experimental design consisted of a time series of measurements at $120 \mathrm{~min}, 180 \mathrm{~min}$ and $300 \mathrm{~min}$ posttreatment, followed by analysis of the elimination rate constant $\left(\mathrm{K}_{\mathrm{el}}\right)$ and limit of quantification for method analysis (10).

\section{Sample preparation}

Certified reference material of Ractopaminehydrochloride (Vetranal) at HPLC grades was purchased from Sigma-Aldrich in CAS-N0 90274-24-1 at level of purity $95.5 \%$. Pharmaceutical-grade ractopaminehydrochloride was produced by Shanghai Hannochem International Corporation. (www.hannochem.com). The drug was dissolved in aqua pro injection solution $(\mathrm{w} / \mathrm{v})$, and drops of $0.1 \%$ phosphoric acid for HPLC grade (Merck Catalog No.7664-38-2) were added until a solution formed. $\mathrm{pH}$ was adjusted 6.8-7 using with $0.1 \mathrm{M} \mathrm{NaOH}$. After filtration through a $0.20 \mu \mathrm{m}$ filter, the solution of ractopamine was ready to use for injection (11). One milligram of the drug was intravenously injected into the jugular veins of goats and sheep. Jugular blood was sampled with a disposable syringe $(5 \mathrm{~mL})$ at $120 \mathrm{~min}, 180 \mathrm{~min}$ and 300 min post-treatment. All samples were placed in $10 \mathrm{~mL}$ heparinized tubes and centrifuged at $3500 \mathrm{rpm}$ for $30 \mathrm{~min}$. The plasma samples were placed in Nunc tubes $(5 \mathrm{~mL})$ and stored at $-20^{\circ} \mathrm{C}$ until all samples were prepared.

\section{Analysis of ractopamine}

Analysis of the drug and drug residues in the liver was performed using a Shimadzu HPLC LC-6AD pump with a PDA detector. Optimization and validation of the HPLC method were modified with the mobile phase consisted of acetonitrile: aqua pro chromatography reagent (30:70) containing $0.1 \%$ phosphoric acid at pH 3.8 (11-13). A reverse-phase ODS $\mathrm{C}_{18}$ column was used, and the detector was set at $225 \mathrm{~nm}$. Rheodyne ${ }^{\circledR}$ sample loops were configured to perform $2 \mu \mathrm{L}$ injections (14). Analysis was carried out using isocratic elution without internal standards. Analysis of the method parameters resulted in an optimal flow rate of $0.5 \mathrm{~mL} \cdot \mathrm{min}^{-1}$ and an analysis time of $20 \mathrm{~min}$. The method was validated for quality assurance at high impact levels according to the new research report $(7,8,10)$.

\section{Analysis of withdrawal time}

The withdrawal time was calculated by using new method namely "Lazuardi Theory" base on $\mathrm{K}_{\mathrm{el}}$ data for ractopamine to determine the elimination half-live $\left(\mathrm{T}_{1 / 2 \beta}\right)$ and the limit of quantification (LOQ), as described by equation at below $(7,9,14)$. The drug residues in goat and sheep in liver were monitored one-month post treatment. 


\section{Statistical analysis}

The relationship between the ractopamine concentration and HPLC detector response and the differences in the kinetics profiles based on goat versus sheep data were assessed with SPSS 24.0 at $5 \%$ significance. The research hypothesis was tested at significance 5\% with SPSS 24.0

\section{Results}

Validation method and concentration of ractopamine in matrix biology

The optimal UV-Vis wavelength for ractopamine detection was $225 \mathrm{~nm}$, as indicated in Fig. 1. The HPLC retention time was $3.890 \mathrm{~min}$ for the ractopamine standard (Fig. 2) but $4.082 \mathrm{~min}$ for ractopamine extracted plasma by SPE (Fig. 3).

The peak area of ractopamine increased linearly with the concentration over the evaluated range of 0.242 to 1.601 $\mu \mathrm{g} . \mathrm{mL}^{-1}$, with a regression equation of $\mathrm{Y}=-0.205+$ $33925175 \mathrm{X}$ and an $\mathrm{R}$-squared value of 0.99 . The coefficients of variation (CVs) for the intraday precision and accuracy at concentrations ranging from $0.18 \mu \mathrm{g} \cdot \mathrm{mL}^{-1}$ to $0.956 \mu \mathrm{g} \cdot \mathrm{mL}^{-1}$ were less than $8 \%$ (Table 1 ).

Regarding method sensitivity, the limit of detection (LOD) was $3.5 \times 10^{-6} \mu \mathrm{g} . \mathrm{mL}^{-1}$, and the LOQ was $1.06 \times 10^{-5}$ $\mu \mathrm{g} . \mathrm{mL}^{-1}$. The precision and accuracy had CVs of less than $20 \%$, and the percent recovery in artificial plasma was more than $80 \%$ (Table 2). The plasma concentrations of the drug in goats and sheep are detailed in Table 3.

\section{Kinetic parameters of ractopamine}

The exponent equation $\left(\mathrm{K}_{\mathrm{el}}\right)$ and $\mathrm{T}_{1 / 2 \beta}$ determined on the basis of the data from goat and sheep between 5- $300 \mathrm{~min}$ post-treatment are presented in Table 4 . These data show that the drug was eliminated more slowly in the goat than in the sheep $(\mathrm{P}>0.05)$.

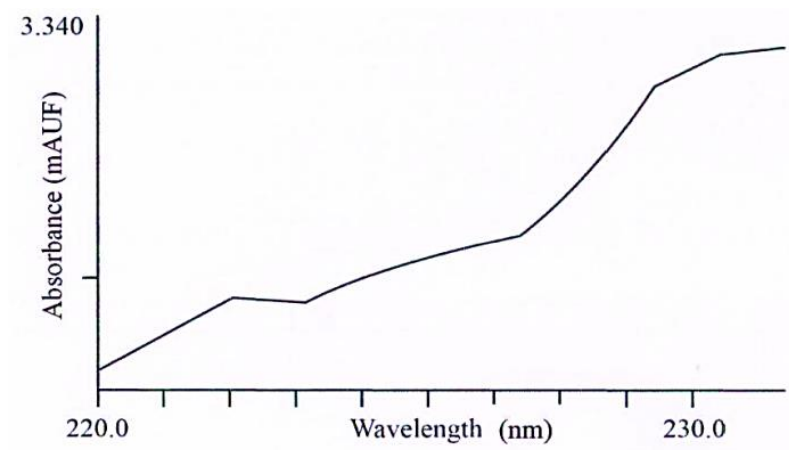

Figure 1: Spectrum of $440 \mu \mathrm{g} \cdot \mathrm{mL}^{-1}$ ractopamine dissolved in acetonitrile:water (30\%:70\%) containing $0.1 \%$ phosphoric acid (pH 3.8), showing the suitable wavelength of $225 \mathrm{~nm}$ with a peak of 0.0150 to $0.020 \mathrm{mAUF}$.

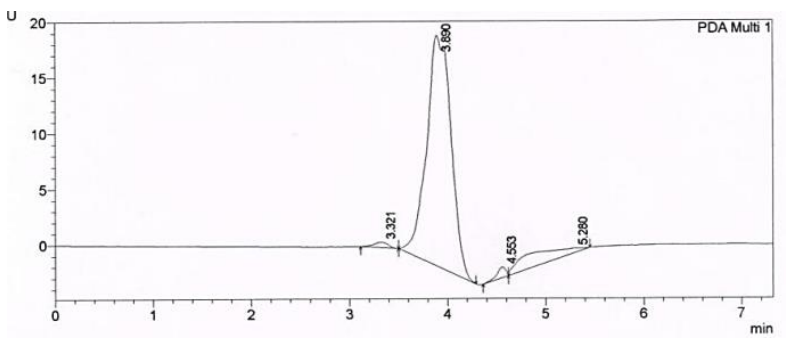

Figure 2: Chromatogram of $50 \mu \mathrm{g} . \mathrm{mL}^{-1}$ ractopamine dissolved in the mobile phase (acetonitrile:water (70:30) containing $0.1 \%$ phosphoric acid, $\mathrm{pH} 3.8$ ) detected at 225 $\mathrm{nm}$, with a retention time of $3.890 \mathrm{~min}$ at $25^{\circ} \mathrm{C}$.

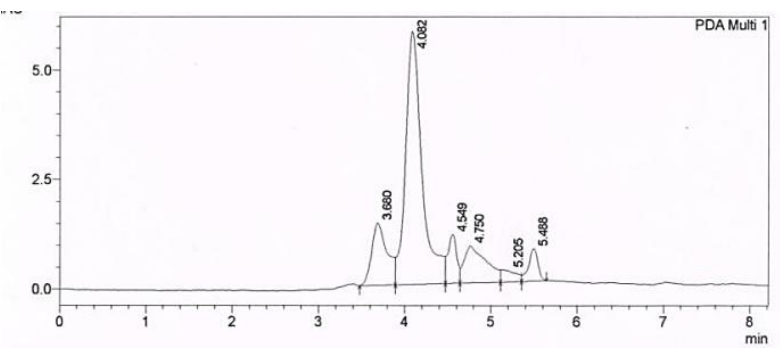

Figure 3: Chromatogram of $0.505 \mu \mathrm{g} . \mathrm{mL}-1$ ractopamine dissolved in the mobile phase (acetonitrile: water (70:30) containing $0.1 \%$ phosphoric acid, $\mathrm{pH} 3.8$ ) at $225 \mathrm{~nm}$, with a retention time of $4.082 \mathrm{~min}$ at $25^{\circ} \mathrm{C}$.

Table 1: Intra-day precision and accuracy for the determination of ractopamine in the eluent mobile phase

\begin{tabular}{ll}
\hline $\begin{array}{l}\text { Ractopamine concentration } \\
\left(\mu \mathrm{g} . \mathrm{mL}^{-1}\right)\end{array}$ & Peak area \\
\hline 0.18 & 6106531 \\
0.19 & 6116641 \\
0.17 & 6006429 \\
\hline Average $=0.18$ & Average $=6076533.667$ \\
$\% \mathrm{CV}=5.555$ & $\% \mathrm{CV}=1.002$ \\
\hline 0.55 & 18658846 \\
0.54 & 17957745 \\
0.56 & 18758856 \\
\hline Average $=0.55$ & Average $=18458482.33$ \\
$\% \mathrm{CV}=1.818$ & $\% \mathrm{CV}=2.365$ \\
\hline 0.78 & 28453985 \\
0.74 & 24413580 \\
0.76 & 26433782 \\
\hline Average $=0.76$ & Average $=26433782.33$ \\
$\% \mathrm{CV}=2.631$ & $\% \mathrm{CV}=7.642$ \\
\hline 0.94 & 35469650 \\
0.97 & 38499855 \\
0.96 & 37488754 \\
\hline Means $=0.956$ & Average $=37152753$ \\
$\% \mathrm{CV}=1.597$ & $\% \mathrm{CV}=4.152$ \\
\hline
\end{tabular}


Table 2: Analysis precision, accuracy and percent recovery for ractopamine in artificial plasma $\left(\mu \mathrm{g} . \mathrm{mL}^{-1}\right)$

\begin{tabular}{lccc}
\hline Drug concentration & Observed drug concentration & Peak area of analyte & Recovery (\%) \\
\hline \multirow{2}{*}{0.25} & 0.200 & 6665032.444 & 80 \\
& 0.220 & 7610343.295 & 88 \\
& 0.240 & 8039522.042 & 96 \\
\hline Average $\pm \% \mathrm{CV}$ & $0.22 \pm 9.091$ & $7438299.29 \pm 9,454$ & $88 \pm 0.022$ \\
0.50 & 0.420 & 14266327.55 & 84 \\
& 0.480 & 16284083.8 & 96 \\
\hline Average $\pm \% \mathrm{CV}$ & 0.530 & 17980342.55 & $95.33 \pm 11.55$ \\
\hline \multirow{2}{*}{1.00} & $0.477 \pm 11.53$ & $16176917.97 \pm 11.494$ & 101 \\
& 1.010 & 34264426.55 & 97 \\
\hline Average $\pm \% \mathrm{CV}$ & 0.970 & 32907419.55 & 98 \\
\hline
\end{tabular}

Table 3: Concentration of ractopamine in goat and sheep plasma

\begin{tabular}{lcccccc}
\hline \multirow{2}{*}{ Animal $(\mathrm{N})$} & \multirow{2}{*}{ Time $(\mathrm{min})$} & \multicolumn{5}{c}{ Drug concentration in plasma samples $\left(\mu \mathrm{g} . \mathrm{mL}^{-1}\right)$} \\
\cline { 3 - 6 } & 5 & 1 & 2 & 3 & 4 & 5 \\
\multirow{4}{*}{ Goat } & 120 & 858.022 & 985.214 & 923.071 & 915.244 & 899.323 \\
& 180 & 600.450 & 540.340 & 805.540 & 814.320 & 811.040 \\
& 300 & 250.120 & 351.050 & 569.130 & 600.120 & 501.110 \\
\multirow{4}{*}{ Sheep } & 5 & 891.260 & 910.060 & 270.230 & 352.420 & 249.120 \\
& 120 & 815.150 & 767.270 & 717.060 & 991.210 & 887.220 \\
& 180 & 599.040 & 600.010 & 598.240 & 614.230 & 616.260 \\
& 300 & 151.250 & 249.140 & 250.430 & 249.530 & 601.150 \\
\end{tabular}

Table 4: Exponential equation, elimination rate constant, elimination half-life, withdrawal time in goat sheep

\begin{tabular}{|c|c|c|c|c|c|c|c|c|}
\hline \multirow[b]{2}{*}{ Animal } & & \multirow[b]{2}{*}{$\begin{array}{l}\text { Exponent } \\
\text { equation }\end{array}$} & \multirow[b]{2}{*}{$\mathrm{R}^{2}$} & \multirow[b]{2}{*}{$\begin{array}{c}\mathrm{K}_{\mathrm{el}} \\
\left(\min ^{-1}\right)\end{array}$} & \multirow[b]{2}{*}{$\begin{array}{l}\mathrm{T}_{1 / 2 \beta} \\
(\mathrm{min})\end{array}$} & \multicolumn{3}{|c|}{ Withdrawal time } \\
\hline & & & & & & $\begin{array}{c}\text { Safety Factor } \\
1 \text { (hours) }\end{array}$ & $\begin{array}{c}\text { Safety Factor } \\
2 \text { (days) }\end{array}$ & $\begin{array}{l}\text { Safety Factor } \\
3 \text { (days) }\end{array}$ \\
\hline \multirow{5}{*}{ Goat } & 1 & $\mathrm{Y}=1117.9 \cdot \mathrm{e}^{-0.005 \mathrm{X}}$ & 0.8887 & $0.005^{\mathrm{a}}$ & 138.600 & 927.882 & $77.323^{\mathrm{c}}$ & $115.985^{\mathrm{e}}$ \\
\hline & 2 & $\mathrm{Y}=1082.3 \cdot \mathrm{e}^{-0.004 \mathrm{X}}$ & 0.9214 & $0.004^{\mathrm{a}}$ & 173.250 & 1159.853 & $96.654^{c}$ & $144.982^{\mathrm{e}}$ \\
\hline & 3 & $Y=11051 . e^{-0.004 X}$ & 0.8999 & $0.004^{\mathrm{a}}$ & 173.250 & 1159.853 & $96.654^{\mathrm{c}}$ & $144.982^{\mathrm{e}}$ \\
\hline & 4 & $Y=1041 . e^{-0.003 X}$ & 0.9162 & $0.003^{\mathrm{a}}$ & 231.000 & 1546.47 & $128.872^{c}$ & $193.309^{\mathrm{e}}$ \\
\hline & 5 & $Y=1087.1 \cdot \mathrm{e}^{-0.005 \mathrm{X}}$ & 0.8975 & $0.005^{\mathrm{a}}$ & 136.600 & 914.492 & $76.208^{c}$ & $114.311^{\mathrm{e}}$ \\
\hline \multicolumn{3}{|c|}{ Mean \pm SD } & & & & $1141.71 \pm 255.85$ & $95.142 \pm 21.321$ & $142.71 \pm 31.982$ \\
\hline \multirow{5}{*}{ Sheep } & 1 & $Y=1257.6 . e^{-0.006 X}$ & 0.8052 & $0.006^{\mathrm{b}}$ & 115.500 & 773.235 & $64.436^{\mathrm{d}}$ & $96.654^{\mathrm{f}}$ \\
\hline & 2 & $Y=1106.1 e^{e-0.004 X}$ & 0.8818 & $0.004^{\mathrm{b}}$ & 173.250 & 1159.852 & $96.654^{\mathrm{d}}$ & $144.981^{\mathrm{f}}$ \\
\hline & 3 & $Y=1084.4 \cdot e^{-0.004 X}$ & 0.9011 & $0.004^{\mathrm{b}}$ & 173.250 & 1159.852 & $96.654^{\mathrm{d}}$ & $144.981^{f}$ \\
\hline & 4 & $Y=1058 . e^{-0.005 x}$ & 0.9882 & $0.005^{\mathrm{b}}$ & 138.600 & 927.882 & $77.323^{\mathrm{d}}$ & $115.985^{\mathrm{f}}$ \\
\hline & 5 & $Y=1123 \cdot e^{-0.005 x}$ & 0.8902 & $0.005^{\mathrm{b}}$ & 138.600 & 927.882 & $77.323^{\mathrm{d}}$ & $115.985^{\mathrm{f}}$ \\
\hline \multicolumn{6}{|c|}{ Mean \pm SD } & $989.741 \pm 167.633$ & $82.478 \pm 13.969$ & $123.717 \pm 20.954$ \\
\hline
\end{tabular}

Superscript a vs. $\mathrm{b}$ in the same column by Independent-Sample t test indicates a significant not-difference at $\mathrm{P}>0.05$.

Superscript $\mathrm{c}$ and e vs. $\mathrm{d}$ and $\mathrm{f}$ in the same column by Independent-Sample $\mathrm{t}$ test indicates a significant not-different at 0.05 .

\section{Discussion}

To determine the ractopamine levels in plasma collected from healthy goats and sheep treated with this agent, we initially utilized the HPLC assay described by other researchers without modification $(9,15,16)$. However, we were unable to reproduce the reported assay so we developed a simpler assay using an isocratic mobile phase. Our protocol 
was validated and the $\mathrm{CV}$ from linearity analysis was no more than $10 \%$. For intra-day precision and accuracy, CVs were less than $20 \%$. We needed to analyse plasma samples containing low concentrations of ractopamine, below 1.00 $\mu \mathrm{g} . \mathrm{mL}^{-1}$, because such concentrations are expected in animals receiving a typical dose regimen but measurements at this level are known to be un certainty, primary due to instrument error and human error during sample preparation. The LOQ we achieved $\left(1.06 \times 10^{-5} \mu \mathrm{g} \cdot \mathrm{mL}^{-1}\right)$ was lower than the mean ractopamine concentration at $300 \mathrm{~min}$ posttreatment in goats and sheep. To produce an accurate, simple assay with high recoveries, sample components were separated on two adsorption columns: an HPLC column and SPE column $(17,18)$. The recovery of ractopamine from plasma was $88-99 \%(19,20)$, consistent with reported recoveries of the half-life in these two species $(21,22)$. and supporting suggestions that it is more extensively distributed in goat tissues than in sheep tissues $(23,24)$. Therefore, in goats, ractopamine is not easily metabolized and must be processed more than 1.15 times as much as in sheep. Overall. It is clear that the risk of exposure to ractopamine residues is greater in goat tissues than in sheep tissues $(4,25)$. The residues in liver and became undetectable after $95 \mathrm{~h}$ in goat and $82 \mathrm{~h}$ in the sheep, similar to delays reported for clenbuterol, a $\beta_{2}$-agonist, in goat tissues $(8,26)$. No ractopamine residues were detected in liver samples at a safety factor of 2 and 3, comparable to the factors reported by Ho and Colleagues the rat (27).

Ractopamine is known for its potential to be distributed into deep tissues in organs such the spleen, liver and kidney, increasing the risk of cancer (28). It is therefore important to acknowledge the risk of residues in animal slaughtered before the end of the withdrawal period. It is known that ractopamine residues do not melt at temperatures of 100-120 ${ }^{0} \mathrm{C}$ so imperfectly cooked meat will lead to the consumption of residues so persistent consumption is likely to increase the risk of cancer.

\section{Conclusions}

The withdrawal time of $1 \mathrm{mg}$ of ractopamine administered intravenously is longer in goats than that in sheep. In goats, the withdrawal time is 3 months and 5 days post-treatment at a safety factor of two, and 4 months and 8 days post-treatment at a safety factor of three. In sheep, the withdrawal time is 2 months and 22 days post-treatment at a safety factor of two, and 4 months and 4 days post-treatment at a safety factor of three. It is clear that, more research is still needed to improve the detection of ractopamine residues in various tissues. A safety factor of more than 3 will be increase confidence that all residues had disappeared.

\section{Acknowledgements}

We thank to Directors of Tropical Diseases Research Center University of Airlangga for supporting the facilities of samples preparations and working by HPLC and spectrometry instruments. This work was financially supported by the Ministry of Research, Technology and Higher Education, Republic of Indonesia by scheme Hibah Kompetisi contract no. 018/SP2H/LT/DRPM/II/2016, February, $17^{\text {th }} 2016$. Thank you to Prof. Graeme B. Martin from University of Western Australia to correction English editing as a joint Adjunct Professor Program between Faculty of Veterinary Medicine University of Airlangga and University Western of Australia.

\section{Conflict of interest}

The authors declare that they have no conflict of interest.

\section{References}

1. Yang F, Yang YR, Wang L, Huang XH, Qiao G, Zeng ZL. Estimating marbofloxacin withdrawal time in broiler chickens using a population physiologically based pharmacokinetics model. J Vet Pharmacol Ther. 2014;37:579-588. DOI: 10.1111/jvp.12137.

2. Liu X, Grandy DK, Janowsky A. Ractopamine, a livestock feed additive, is a full agonist at trace amine-associated receptor 1. J Pharmacol Exp Ther. 2014;350:124-129. DOI: 10.1124/jpet. 114.213116.

3. Jiang D, Cao B, Wang M, Yang H, Zhao K, Li J, Li M, Sun L, Deng A. Development of a highly sensitive and specific monoclonal antibodybased enzyme-linked immunosorbent assay for the detection of a new beta-agonist, phenylethanolamine A, in food samples. J Sci Food Agric. 2017;97:1001-1009. DOI: 10.1002/jsfa.7826.

4. Pleadin J, Vulic A, Persi N, Terzic S, Andrisic M, Žarkovic I, Šandor K, Perak E, Mihaljevic Z. Accumulation of ractopamine residues in hair and ocular tissues of animals during and after treatment. J Anal Toxicol. 2013;37:117-121.DOI: 10.1093/jat/bks092 .

5. Regal P, Diaz-Bao M, Barreiro R, Vazquez BI, Cepeda A. Confirmation of beta-agonist residues in bovine retina and liver using HPLC-MS/MS and evaluation of matrix-dependent problems. Food Addit Contam Part A Chem Anal Control Expo Risk Assess. 2017;34:598-607.DOI: 10.1080/19440049.2016.1271144

6. Lazuardi M. The Generaly Part of Veterinary Pharmacy Sciency. $1^{\text {st }}$ Ed. Jakarta, Indonesia: Ghalia Indonesia.;2016. 29-42 p.

7. Lazuardi M. The Special Part of Veterinary Pharmacy Science. $1^{\text {st }}$ Ed. Surabaya-Indonesia: Airlangga University Press. 2019. 249-250 p.

8. Lazuardi M, Hermanto B. High-performance liquid chromatography ultraviolet-photodiode array detection method for aflatoxin $B_{1}$ in cattle feed supplements. Vet World. 2017;10:932-938.DOI: 10.14202/vetworld.2017.932-938

9. Lazuardi M, Hermanto B, Restiadi TI. Calculate of withdrawal times of clenbuterol in goats to obtain safe times of slaughter. Vet World. 2018;11:731-738. DOI: 10.14202/vetworld.2018.731-738

10. Li L, Tang C, Zhang J, Zhao Q, Zhang K.The potential of various living tissues for monitoring clenbuterol abuse in food-producing Chinese simmental beef cattle. J Anal Toxicol. 2016. 40:72-77.DOI: 10.1093/jat/bkv118

11. Chiesa L, Panseri S, Cannizzo FT, Biolatti B, Divari S, Benevelli R, Arioli F, Pavlovic R. Evaluation of nandrolone and ractopamine in the urine of veal calves: liquid chromatography-tandem mass spectrometry approach. Drug Test Anal. 2017;9:561-570.DOI: 10.1002/dta.2026 
12. Lazuardi M, Restiadi TI, Hermanto B. Calculated withdrawal time by lazuardi equation method. Proc Natl Indone Vet Pharm Pharmacol Assoc. 2018;3(1):45-48.

13. Ding G, Li D, Qin J, Zhu J, Wang B, Geng Q, Guo M, Punyapitak D, Cao Y. Development and validation of a high-performance liquid chromatography method for determination of ractopamine residue in pork samples by solid phase extraction and pre-column derivatization. Meat Sci. 2015;106:55-60.DOI: 10.1016/j.meatsci.2015.03.016

14. Wang L, Huang L, Pan Y, Wu Q, Xie S, Yuan Z. Simultaneous determination of aditoprim and its three major metabolites in pigs, broilers and carp tissues, and its application in tissue distribution and depletion studies. Food Addit Contam Part A Chem Anal Control Expo Risk Assess. 2016;33:1299-1311. DOI:10.1080/19440049.2016.1200751.

15. Wu J, Liu X, Peng Y. Determination of ractopamine in pig hair using liquid chromatography with tandem mass spectrometric detection. J Pharmacol Toxicol Methods. 2014;69:211-216.DOI: 10.1016/j.vasen.2014.02.001

16. Pan S, Zhou L, Zhao Y, Chen X, Li X, Jin M. Development and validation of a sensitive method for simultaneous determination of eight beta (2)-agonists in pork by ultrasonic-assisted extraction and liquid chromatography/tandem mass spectrometry. J Chromatogr Sci. 2015;53:104-111.DOI: 10.1093/chromsci/bmu026

17. Du W, Zhao G, Fu Q, Sun M, Zhou H, Chang C. Combined microextraction by packed sorbent and high-performance liquid chromatography-ultraviolet detection for rapid analysis of ractopamine in porcine muscle and urine samples. Food Chem. 2014;145:789795.DOI: 10.1016/j.foodchem.2013.08.094

18. Freire EF, Borges KB, Tanimoto H, Nogueira RT, Bertolini LC, de Gaitani CM. Monitoring of ractopamine concentration in the mixture of this feed additive with vitamin mineral complex and with swine feed by HPLC. Food Addit Contam Part A Chem Anal Control Expo Risk Assess. 2013;30:796-803.DOI: 10.1080/19440049.2013.780213.

19. Wang X, Guo T, Wang S, Yuan J, Zhao R. Simultaneous determination of 11 beta-agonists in human urine using high-performance liquid chromatography/tandem mass spectrometry with isotope dilution. J Anal Toxicol. 2015;39:213-218.DOI: 10.1093/jat/bku143.

20. Chan KW. Validation of a straightforward high-performance liquid chromatographic method formorphine quantitation. Egypt J Forensic Sci. 2017;7:1-6. DOI: 10.1186/s41935-017-0003-0.

21. Smith DJ, Shelver WL, Marx A. Detection of residues in urine and tissues of sheep treated with trace levels of dietary ractopamine HCl. J Anim Sci. 2016;94:5423-5433.DOI: 10.2527/jas.2016-0899

22. Zhao Z, Gu X, Su X, Li J, Li J, Dong Y, Yang Y, Yao T, Qin Y. Distribution and depletion of ractopamine in goat plasma, urine and various muscle tissues. J Anal Toxicol. 2017;41:60-64.DOI: 10.1093/jat/bkw102

23. Tang C, Zhang J, Li L, Zhao Q, Bu D. Ractopamine residues in urine, plasma and hair of cattle during and after treatment. J Anal Toxicol 2014;38:149-154.DOI: 10.1093/jat/bku006

24. Huang L, Shi J, Pan Y, Wang L, Chen D, Xie S, Liu Z, Yuan Z. Elimination and concentration correlations between edible tissues and biological fluids and hair of ractopamine in pigs and goats fed with ractopamine-medicated feed. J Agric Food Chem. 2016;64:20122020.DOI: 10.1021/acs.jafc.6b00456.

25. Pleadin J, Vulic A, Persi N, Terzic S, Andrisic M, Žarkovic I, Šandor $\mathrm{K}$, Perak E. Comparison of ractopamine residue depletion from internal tissues. Immunopharmacol Immunotoxicol. 2013;35:8892.DOI: 10.3109/08923973.2012.702115

26. Edenburn BM, Kneeskern SG, Bohrer BM, Rounds W, Boler DD, Dilger AC, Felix TL. Effects of supplementing zinc or chromium to finishing steers fed ractopamine hydrochloride on growth performance, carcass characteristics, and meat quality. J Anim Sci. 2016;94(2):771779.DOI: $10.2527 /$ jas.2015-9979

27. Ho JK, Huo TI, Lin LC, Tsai TH. Pharmacokinetics of ractopamine and its organ distribution in rats. J Agric Food Chem. 2014;62:92739278.DOI: $10.1021 / \mathrm{jf5026168}$

28. Grandin T. On-farm conditions that compromise animal welfare that can be monitoredat the slaughter plant. Meat Sci. 2017;132:5258.DOI:10.1016/j.meatsci.2017.05.004 